\title{
Forearc Basin: Characteristics of the Subsurface in Magdalena Shelf, Baja California, Mexico, from the Interpretation of Seismic-Reflection Profiles
}

\section{Edgar A Mastache-Román ${ }^{1}$ and Mario González-Escobar ${ }^{\star}$}

${ }^{1}$ Postgradute Earth Sciences, CICESE, Geoexplorer Solutions Company, Mexico

${ }^{2}$ Centro de Investigación Científica y de Educación Superior de Ensenada, B.C., Mexico

\begin{abstract}
Eight seismic reflection profiles, two dimensions, were collected in a sector of the Magdalena Shelf, Baja California, Mexico, which contains a forearc basin, providing a spatial view of faults and seismic reflectors in this basin. Two small asymmetric basins were configured; ToscoAbreojos and San Lázaro controlled by the Tosco-Abreojos and Santa Margarita-San Lázaro Faults. These faults accommodate a great part of the transtensional stress in the shelf and control the bathymetry and show great deformation in the western sector. Seismic horizons illustrate that the depocenter of the San Lazaro basin reaches depths of $\sim 4 \mathrm{~km}$, while the ToscoAbreojos account reaches depths of around $\sim 5.5 \mathrm{~km}$, being present at these depths a diffuse reflector that is considered the acoustic basement. Santa Margarita fault is present in the Santa Margarita and Magdalena islands, extending northwest, then stop presenting its relief represented by the San Lazaro fault, which is associated with the seismic activity resent reported for the region. Reflectors observed to the south of the region, previously reported by other works, were also observed in this area. However, there are new reflectors to the NW, which fill the spaces of both basins, taking a total of eight seismostratigraphic units. Unconformity is present throughout the region that separates the Neogene sequence from the PaleoceneEocene sequence that fills the forearc basin. Below the unconformity, there is a huge packet of Miocene sediments. Structural height corresponding to the subduction complex that extends in the SE-NW direction along the Magdalena Shelf is present, which is considered as the acoustic basement and is attributed to the ophiolite rocks. This structural height can be related to the Alto Lagunitas, located in the central part of Baja California, where an ophiolite rock is also present. But Magdalena Shelf is more recent than the Alto Lagunitas since the said rocks in this place are younger arch. From the results obtained, Santa Margarita Fault should be considered for future risk studies, since it is tectonically active and its path passes near population centers, such as Puerto San Carlos.
\end{abstract}

\section{Keywords}

Forearc basin, Reflection seismic 2D, Seismic processing, Magdalena shelf, Tosco-Abreojos fault, San Lazaro-Santa margarita fault, Basins

\footnotetext{
*Corresponding author: Mario González-Escobar, Centro de Investigación Científica y de Educación Superior de Ensenada, B.C., Mexico, Tel: +521646175-05-00, Ext. 26300

Accepted: December 15, 2020; Published: December 17, 2020

Copyright: (C) 2020 Mastache-Román EA, et al. This is an open-access article distributed under the terms of the Creative Commons Attribution License, which permits unrestricted use, distribution, and reproduction in any medium, provided the original author and source are credited.
}

Mastache-Román and González-Escobar. Int J Earth Sci Geophys 2020, 6:041

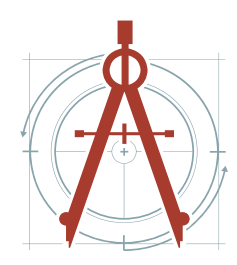




\section{Introduction}

The Baja California micro-plate is a fragment of separated continental crust (detached) from the continental region of Mexico and captured by the Pacific plate 10-15 Ma [1-5]. The formation and subsequent capture of continental microplates in the subduction margins are controlled in some way by the underlying oceanic slab, possibly through the basal or shear traction distributed and transmitted through the continental lithosphere interface $[2,6]$. The flexion's happen during subduction of the Farallon oceanic plate in front of the Mag-

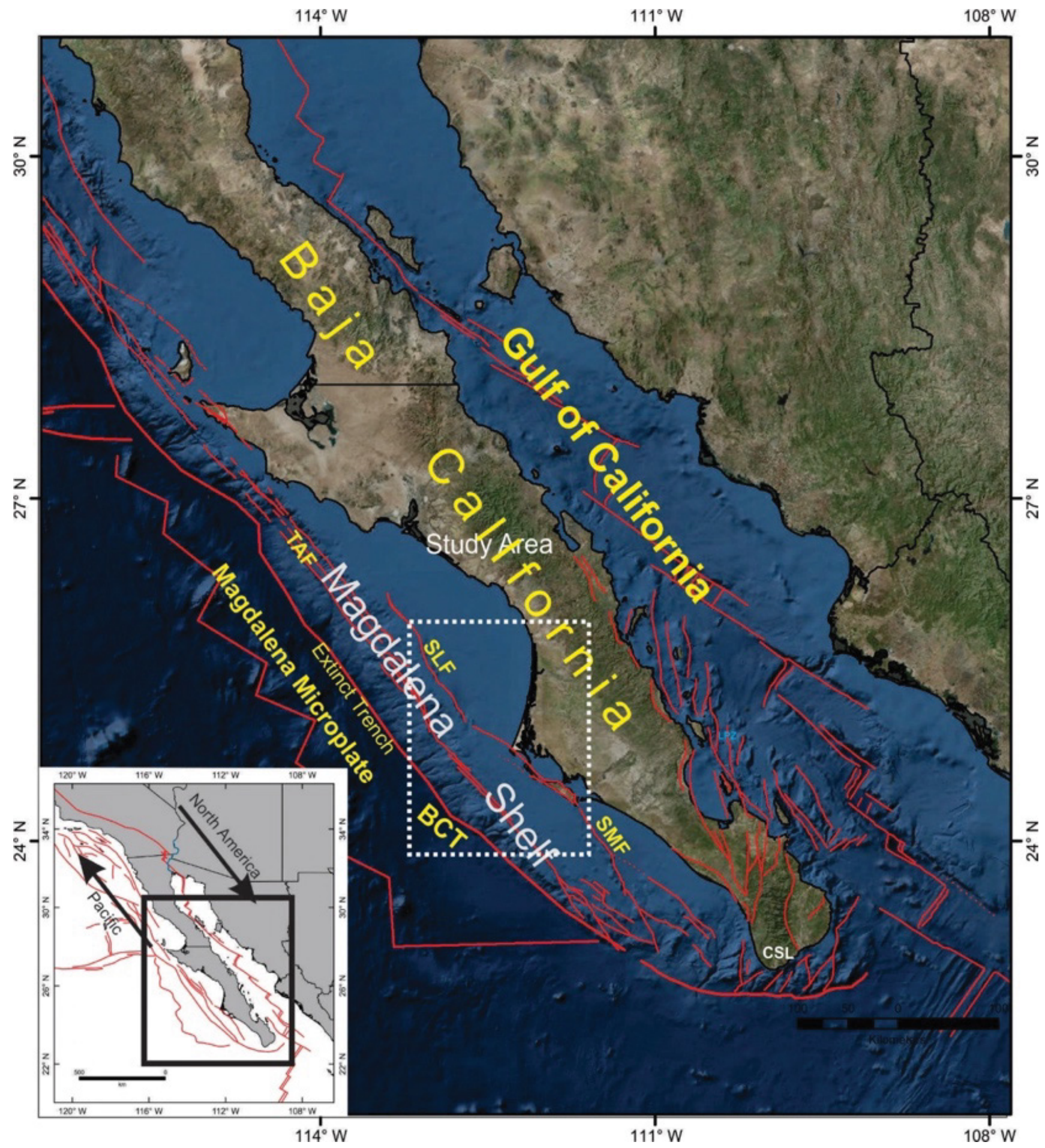

Figure 1: Inset map, study region (black box) and major fault systems in the Baja California-Gulf of California region. The study area lies within the dashed white box. BCT: Baja California Trench; TAF-Tosco: Abreojos Fault; SMF: Santa Margarita Fault; SLF: San Lázaro Fault; LPZ: La Paz; TS: Todos Santos; CSL: Cabo San Lucas. Map generated with information of [2] and [25]. 
dalena Shelf, sub-ducting below the North American plate in southern Baja California, Mexico. As a consequence of the subduction process, the formation of a forearc basin was originated (Figure 1). The forearc basin has an abundant tectonic load that forms a topographic depression (bathymetric) that acts as a sedimentary trap and can accumulate a considerable amount of sediments [7]. To know the tectonostratigraphic characteristics of basins of this type is necessary to have reliable subsoil information, that is, structures and seismostratigraphic characteristics in the area, among other features.

The forearc basins contain an almost continuous record of active marginal sedimentation. During the convergence of the plates and the stratigraph- ic architecture in these basins, the changes in the area of accommodation are reflected, which were formed as a result of the interaction with the descending force of the oceanic plate (tectonics), the sediment load and the static changes in sea level [8]. A clear, comparable example is the case of the forearc of southeastern Crete, east of the Mediterranean [9] since it presents similarity in a complex deformation, and basins with large sedimentary deposits due to the extension through which they tend to form normally.

Having access to seismic data of the petroleum industry, collected by Petróleos Mexicanos (PEMEX) in the early 80s, presents a great opportunity to investigate the subsurface characteristics
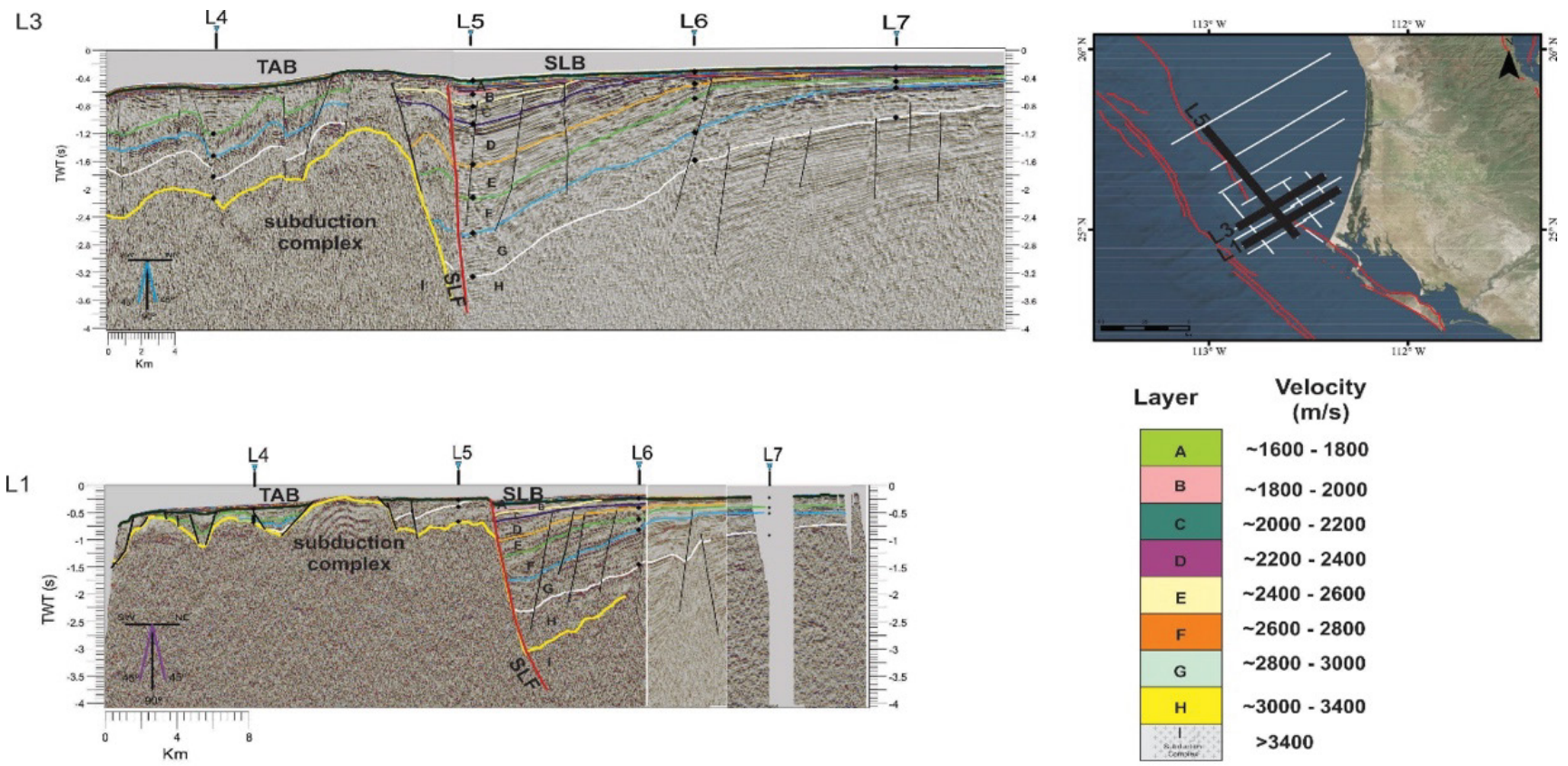

L5
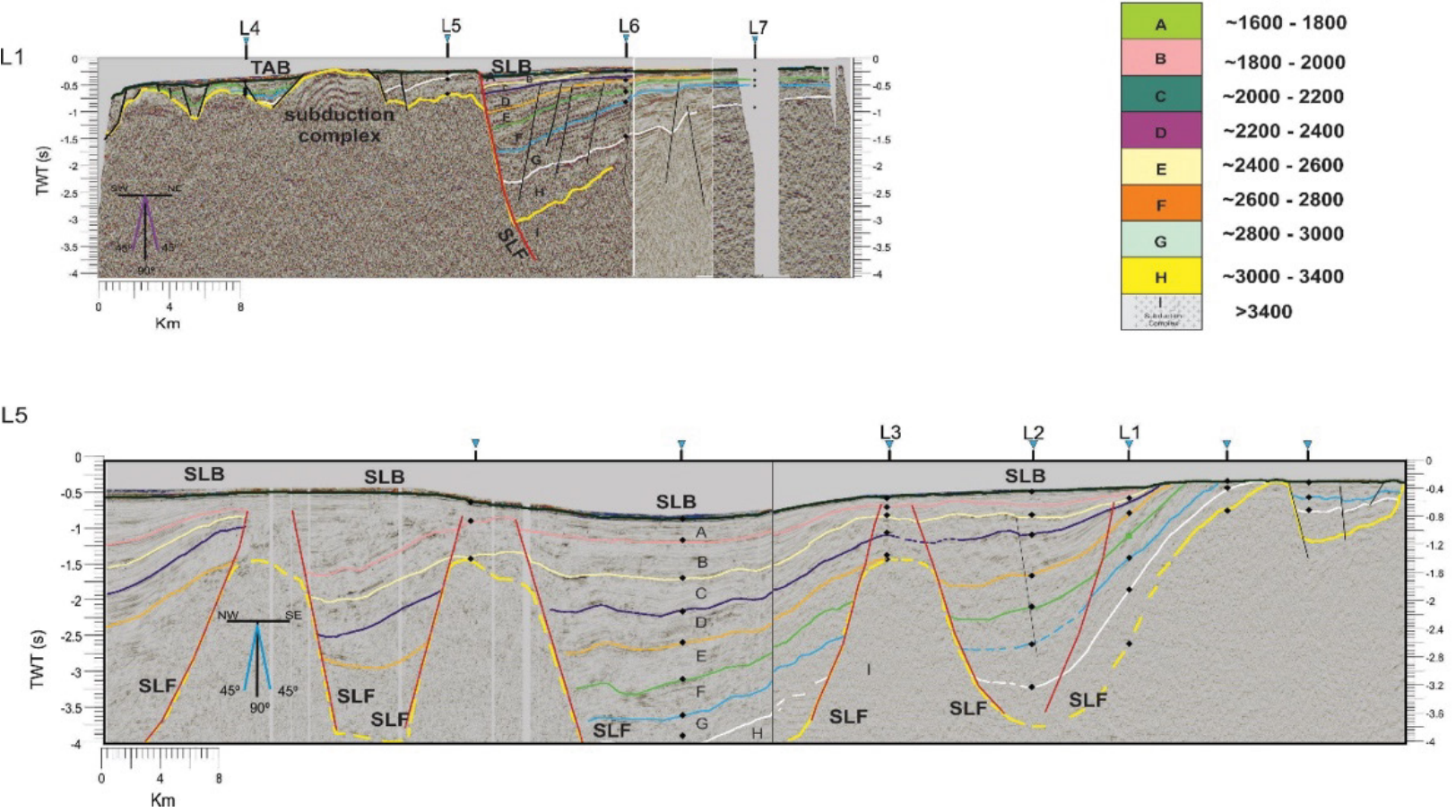

Figure 2: Detail of three seismic profiles interpretation that was used to characterize the study area. Note that the basins are interpreted by identifying the sedimentary package and also be observed the main fault which controls the San Lazaro Basin (SLB). The letters represent different seismic strata with different ranges of velocities and are showing represented by simplified stratigraphic columns with units of velocity. It is observed, how the L5 profile cuts the San Lázaro Fault (SLF) several times. The points in the profiles represent the intercepts of the seismic strata between the longitudinal and transversal profiles in -Tosco-Abreojos Basin (TAB). 
in a section of a forearc basin. The seismic data covers an area of $\sim 350 \mathrm{~km}^{2}$, which helped in obtaining the geometrical characteristics of faults and seismostratigraphic units in the central part of the Magdalena Shelf (Figure 2). The present work includes the processing and interpretation of eight seismic reflection profiles (Figure 1 and Figure 3), as well as information reported and interpreted by [2] and [10]. The characteristics are presented to have a view of the main structures, their architecture, and the shape of the sedimentary deposits. Subsequently, the distribution of structures and the configuration of the seismic stratigraphic units are discussed.

\section{Forearc Basin}

The forearc basin has a set of sedimentary deposits within it (Figure 3 ) and is located between the oceanic trench and the volcanic arc, in this case, Comondú [11], that is, inside an accretion prism near the area of subduction. It is part of a subduction complex that forms the crest of the trench and the volcanic arc due to the flexion and subduction of the oceanic plate [12]. The flexion of the continental wedge during subduction resulted in fracture and faulting in the area, so that the flexure of the continental wedge acted as a sediment trap [13] in which the sinking of the basin is controlled by the negative buoyancy of the oceanic crust, subsidence due to bending of the subsurface and loading of lithostatic sediments [8].

\section{Geological Settings}

The tectonic evolution of northwestern Mexico is closely related to the changes between the limit of North American and the Pacific-Farallón plates. From the Triassic-Jurassic, which has evolved from a subduction system to an ocean-continental rupture system, with the transfer of the Baja California peninsula to the Pacific plate during the late Miocene-Pliocene $(<12 \mathrm{~mA})[13,14]$. The Mesozoic rocks that make up the peninsula are one of the best subduction assemblages exposed in a convergent margin, with the development of a forearc basin between the accretion prism and the volcanic arc, in this case, Comondú (Figure 3 ) according to [15].

The main structures in the study area are the fault systems; Tosco-Abreojos and Santa Margarita-San Lázaro (Figure 1). These formed after the beginning of the cessation of the subduction of the Farallon plate under the continent due to the approach of the Pacific-Farallon dorsal to the old trench that marked the end of the subduction, and to initiate a new movement of transformative type between the Pacific and North American plates. The characteristics of the Farallón plate (Guadalupe and Magdalena microplates) indicate a change in the angle of convergence before the cessation of subduction in the early Miocene that caused the development of this fault system $[4,16]$. The fault cuts the forearc basin above the system, which extends along the Magdalena Shelf from SE to NW.

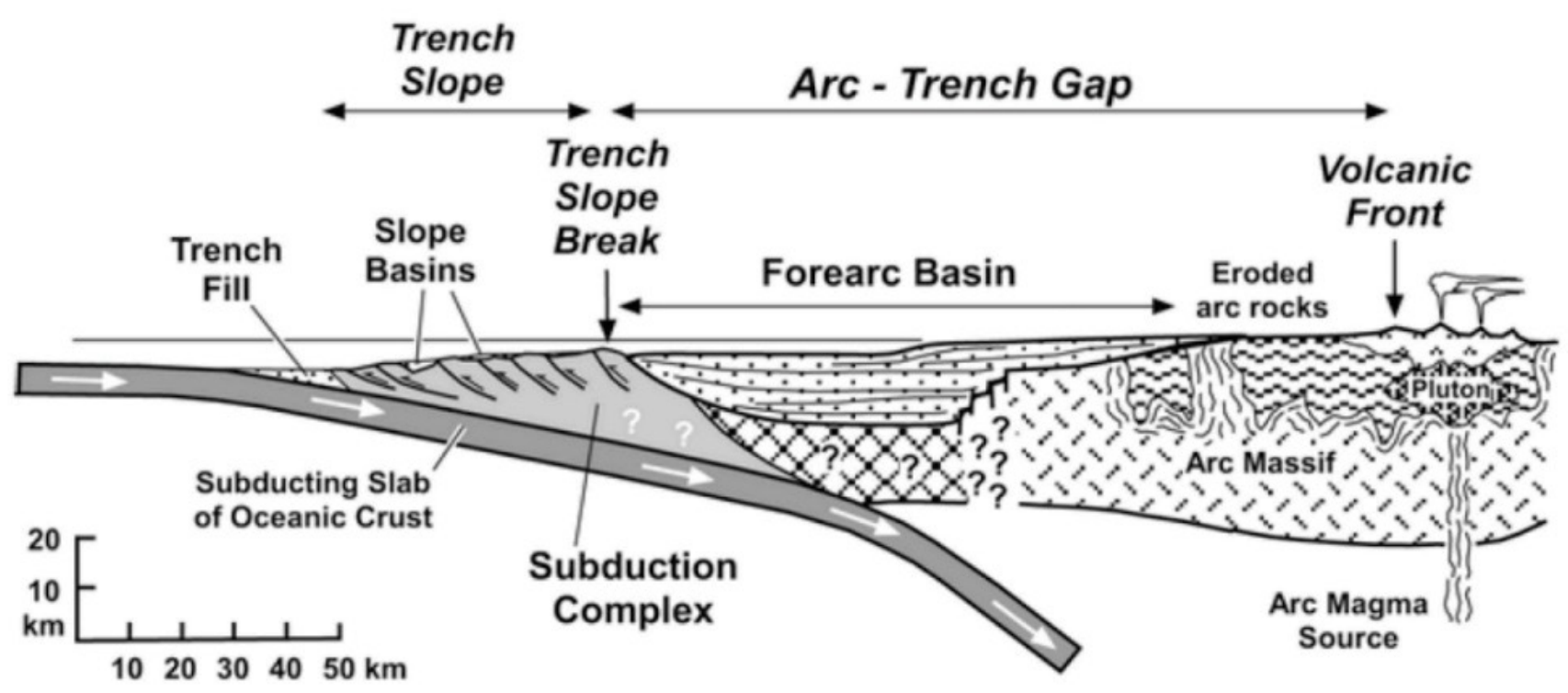

Figure 3: Schematic model of a forearc basin [8]. 
The Tosco-Abreojos fault has a length of $180 \mathrm{~km}$ and depression of $\sim 15 \mathrm{~km}$ of width, with a strike of 3800, while the Santa Margarita fault has a length of $\sim 200 \mathrm{~km}$ which is a relay with the San Lazaro fault, which extends more than $150 \mathrm{~km}$ to the NW. These faults had already been reported, mainly based on bathymetric studies [17]. Subsequently, through seismic profiles made in 2002 during the FAMEX oceanographic campaign [4] and more recently by [10], where the structure of the Magdalena Shelf was characterized, to the south of the area of the present work, the region studied here is not known. These authors report the location and distribution of the faults, but the difference with this work is that it is intended to give a detailed characterization of the Santa Margarita and San Lázaro faults. For this, we analyzed from a set of seismic profiles (net) assisted with a complete anomaly map of Bouguer (Gravimetric) obtained from [18], which allows us to project these faults according to the anomalies. Also, some faults [10], were incorporated in this work, for the correlation.

It is important to mention that the studies carried out to the south of the study area $[2,10]$, show reflectors associated to three main stratigraphic units of the Neogene (A, B and C), where the reflector $C$ is considered as the angular unconformity that separates the Neogene sequence of the Paleocene-Eocene sequence that fills the forearc basin. Below the unconformity, there is a huge packet of Miocene sediments, identified as the oldest $\sim 8 \mathrm{Ma}$ in the northern region of the Magdalena shelf [10]. Although the seismic activity in the region is very low, as reported by [19], it is inferred that the region is tectonically active.

\section{Data Analysis}

The Magdalena Shelf was submitted to an ex-

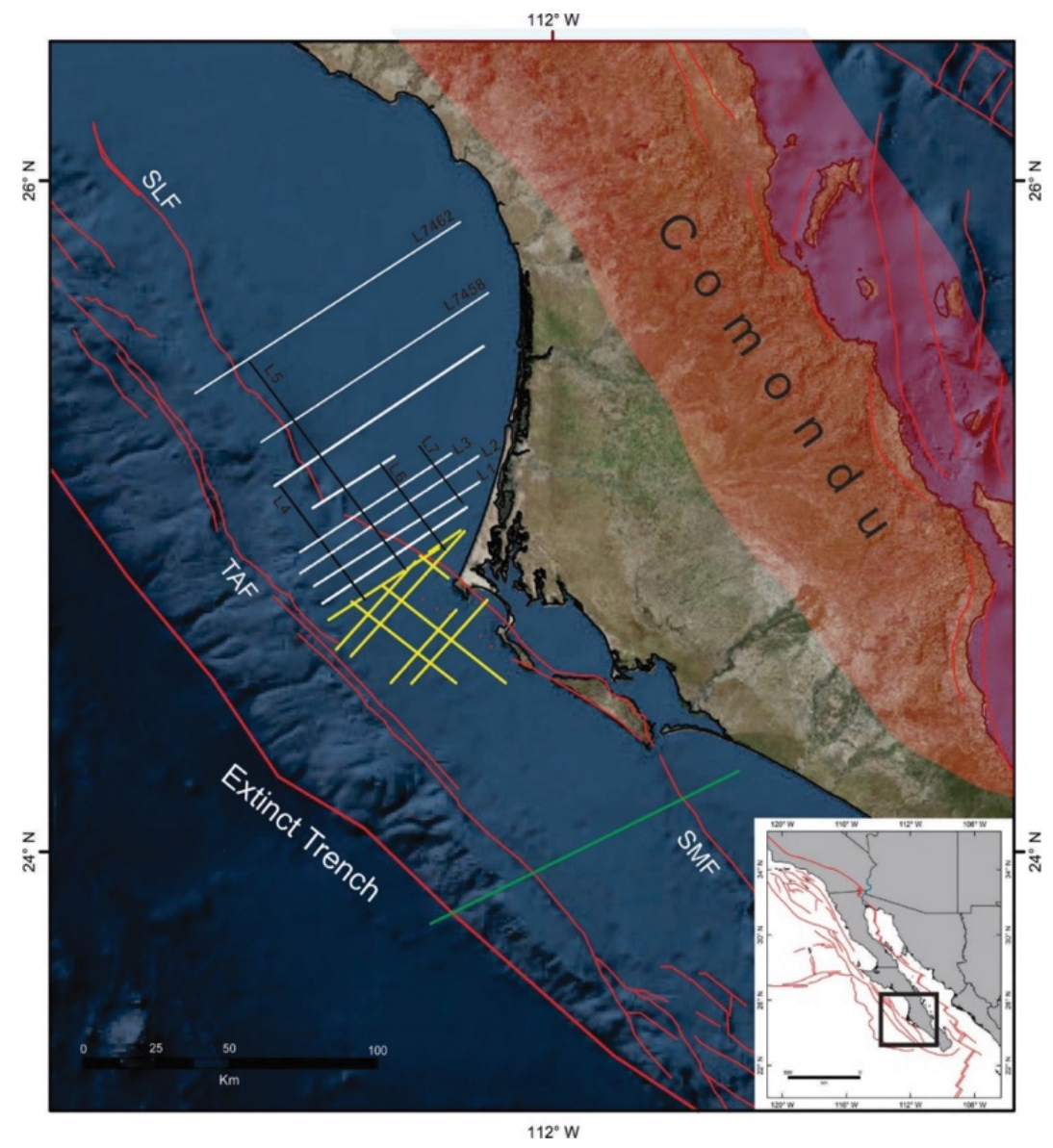

Figure 4: Location of seismic profiles (white and black lines), processed and interpreted for this studio work; yellow seismic profiles are [10] and green profile from [2]. SLF: San Lázaro Fault; SMF: Santa Margarita Fault; TAF: Tosco-Abreojos Fault. Comondú Group [11], color is east sector (cherry color) Miocene Volcanic rocks; central sector (brown color) Plio-Quaternary Volcanic rocks, and west sector (light Green color) Undifferentiated sub-aerial rocks $[25,10]$. 
ploration program collecting seismic reflection 2D data, among others, according the sections of the Figure 4. The seismic processing consisted of: (1) Trace editing; (2) Geometry mapping; (3) Direct wave attenuation; (4) Deconvolution; (5) Frequency filter-wave number; (6) Trace order by common depth point (CDP); (7) Velocity analysis; (8) Normal motion correction (NMO); (9) Stacking; (10) spherical divergence; (11) Time-varying filter; (12) Automatic gain control (AGC) and (13) Migration [20]. Subsequently, the data were interpreted using the technique of [21] in the time domain (Two Way Travel Time-TWTT). The Landmark ${ }^{\mathrm{TM}}$ ProMax and SeisWorks software [22] and OpendTect ${ }^{\mathrm{TM}}$ were used in the processing and interpretation of the data. The interpretation of three seismic profiles can be seen in Figure 2.

\section{Interpretation}

The seismic interpretation consisted of the structural characterization of the subsoil, through the detection of faults and horizons in the seismic profiles. For the detection, faults were identified in discontinuities or sudden jumps between the reflectors, while for the horizons, it was necessary to identify coherent, continuous seismic events with high amplitude contrast. The detection of faults tends to be the first step since it provides the image of the behavior of the structures in the subsoil. Often, faults tend to produce effects such as degradation of the seismic image due to diffraction, so care must be taken in this regard.

One of the most representative and important structures identified in this work is a segment of the San Lázaro fault and can be observed up to $4 \mathrm{~s}$ (TWTT), in depth (Profile L5, Figure 2). This fault is considered to be regional of normal type and listric geometry with a dip of $\sim 45^{\circ}$ and a vertical jump of $\sim 2 s$ (TWTT). Secondary faults develop as a result of the extension that tends to settle the sedimentary deposits, with synthetic and antithetical structures located in the northeastern part that can be observed until 3 .7s (TWTT). Other faults are located to the southwest through a longitudinal structural height that is present along the Magdalena Shelf (Figure 2 and Figure 5). The faults control the structures of the Tosco-Abreojos basin, in this case, fallen blocks controlled by normal faults that do not exceed $1.5 \mathrm{~s}$ in depth in the section of Line 1 and 2.4s (TWTT) for the section of Line 3. The structural height is attributed to the ophiolite rock that com- poses the basement and intrusions in sedimentary sequences in some sections, which separates the Tosco-Abreojos basin from that of San Lazaro (Figure 2 and Figure 6).

In addition to the faults, nine seismic reflectors (horizons) with high acoustic impedance contrast were identified (Figure 2), of which eight are associated with the limit of sedimentary structures and one with the acoustic basement. The reflector of the acoustic base corresponds to the deepest structure; it is very diffuse seismically. This is usually because the reflector is probably associated with magmatic rocks that tend to absorb seismic energy. The acoustic basement was identified in most of the seismic profiles as an antiform, which we call structural height, and is longitudinal along with a large sector of the Shelf and develops two semi-graben controlled by two regional faults (Tosco-Abreojos and Santa Margarita-San Lázaro faults) and some minor extensional faults. At the same time, we helped with the gravimetric anomaly [18], which has a good correlation with the structures identified in the seismic sections. The longitudinal shape of this basement block is irregular, as well as its depth as observed in the topographic form of the acoustic layer (Figure 6).

The acoustic basement reflector is the finale of structures that we can see, because to more deep, the image is diffuse. Regularly this is because as from the final reflective, we have a single rock probably associated with magmatic rocks where the seismic energy is absorbed. It has identified the acoustic basement in most seismic profiles; this has the form of the longitudinal block along the Magdalena shelf that develops as a consequence two half-graben controlled by two regional faults (Tosco-Abreojos and Santa Margarita - San Lazaro faults) and some minor extensional faults. The longitudinal form of this block is irregular because varies the deep in some parts of the basement topography (Figure 6).

A characteristic feature of the acoustic basement is that it delimits the basins; Tosco-Abreojos and San Lazaro (Figure 2). The Tosco-Abreojos basin is made up of several small depocenters (Figure 6), in comparison with the San Lazaro basin, and it is at the end of the structural high. Below these basins is the acoustic basement, which is composed of ophiolite rocks according to [23,24], which are materials resulting from the interaction between 
a)

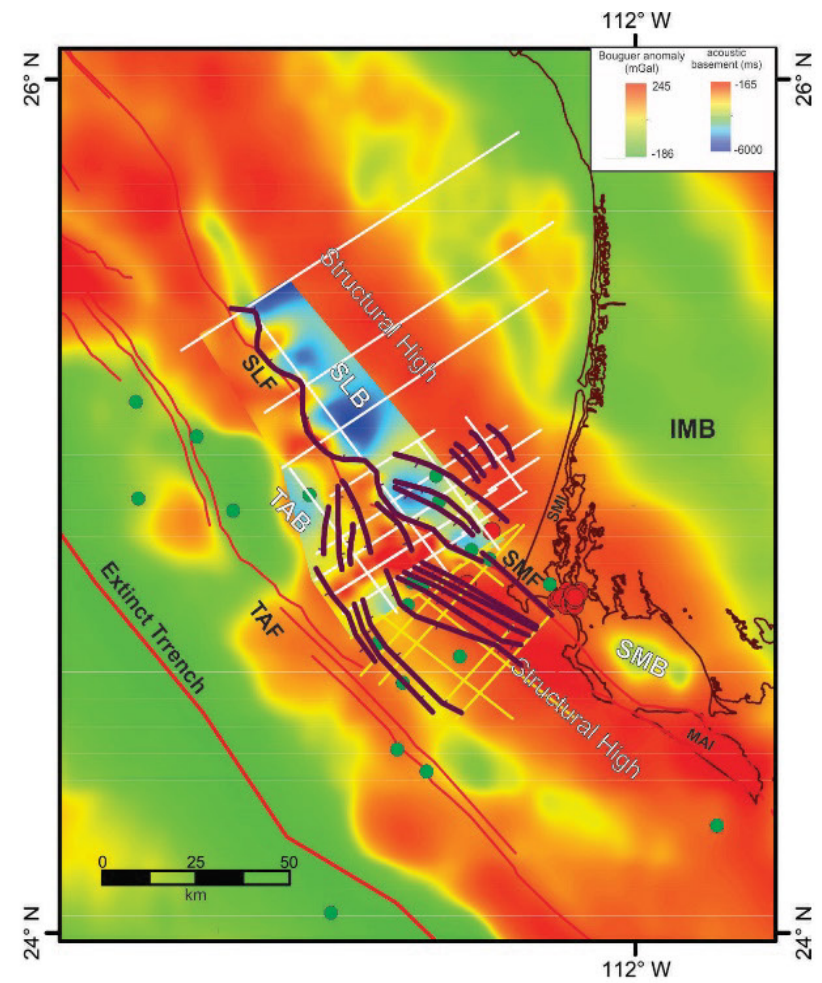

b)

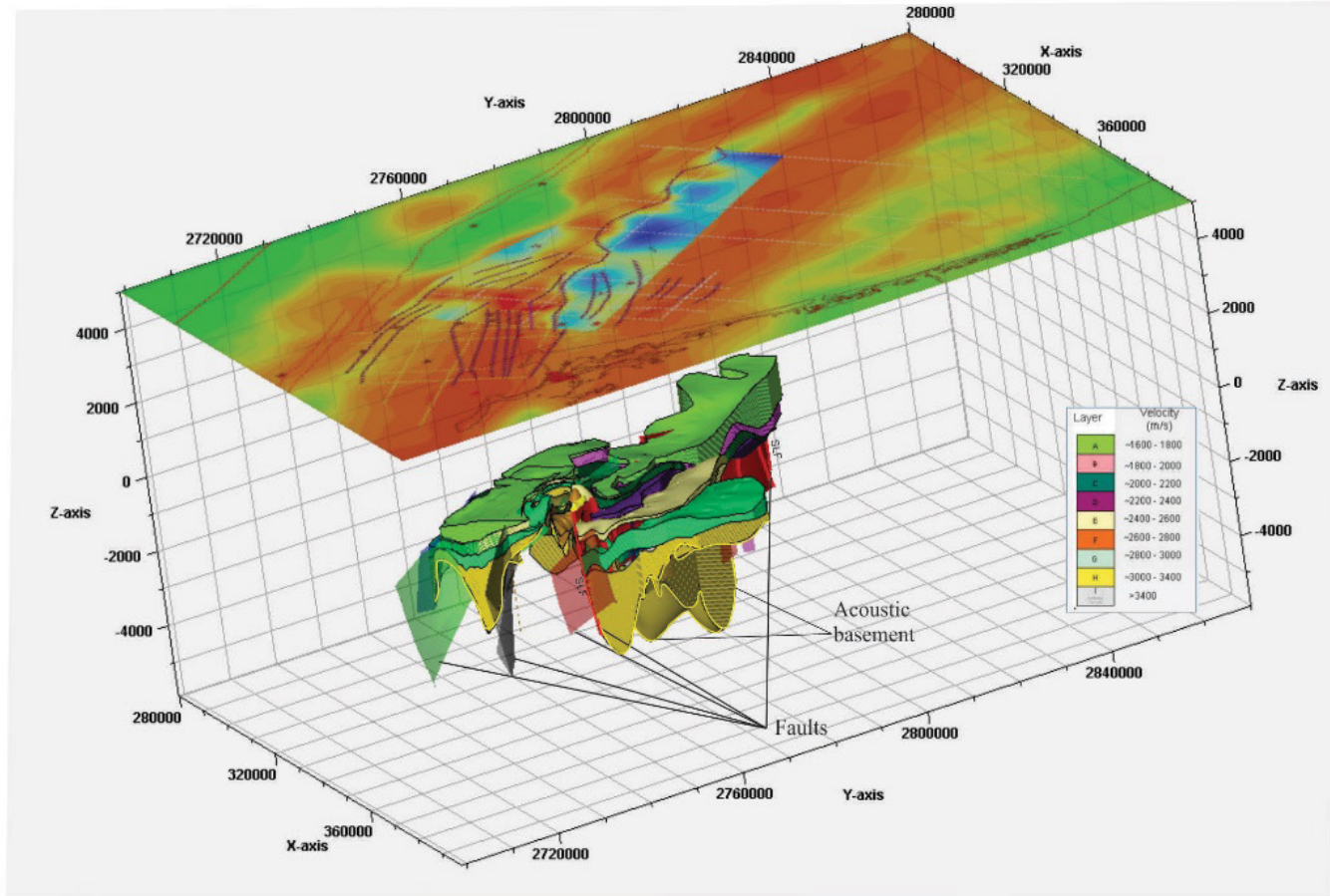

Figure 5: Summary tectonic map of the study region of Magdalena shelf. a) Faults reported in this study (white seismic profiles), yellow seismic profiles reported by [10] and red color are the faults known until before these works $[2,25]$. Colors containing mainly the blue represent the reflective acoustic basement obtained in this work. The seismic profile to the north a structural high with little sedimentary cover is presented and later deepened to the northeast, which is part of the Iray-Magdalena basin, observing sedimentary thicknesses of more than 5 $\mathrm{km}$. The acoustic basement and faults correlate very well with Complete Bouguer anomaly of [18]. SLB and TAB are bigger basins that are configured for the structure of the SLF, which separate both basins. This last fault is observed in Santa Margarita (SMI) and Magdalena (MAI) islands [25]. The relay zone is observed between the SLF to the north and SMF to the south. IMB-Iray-Magdalena Basin and SMB-Santa Margarita Basin from [10]. Red and green are the seismicity reported by [19]; b) Three-dimensional perspective of the interpretation, showing the seismic strata and faults. 


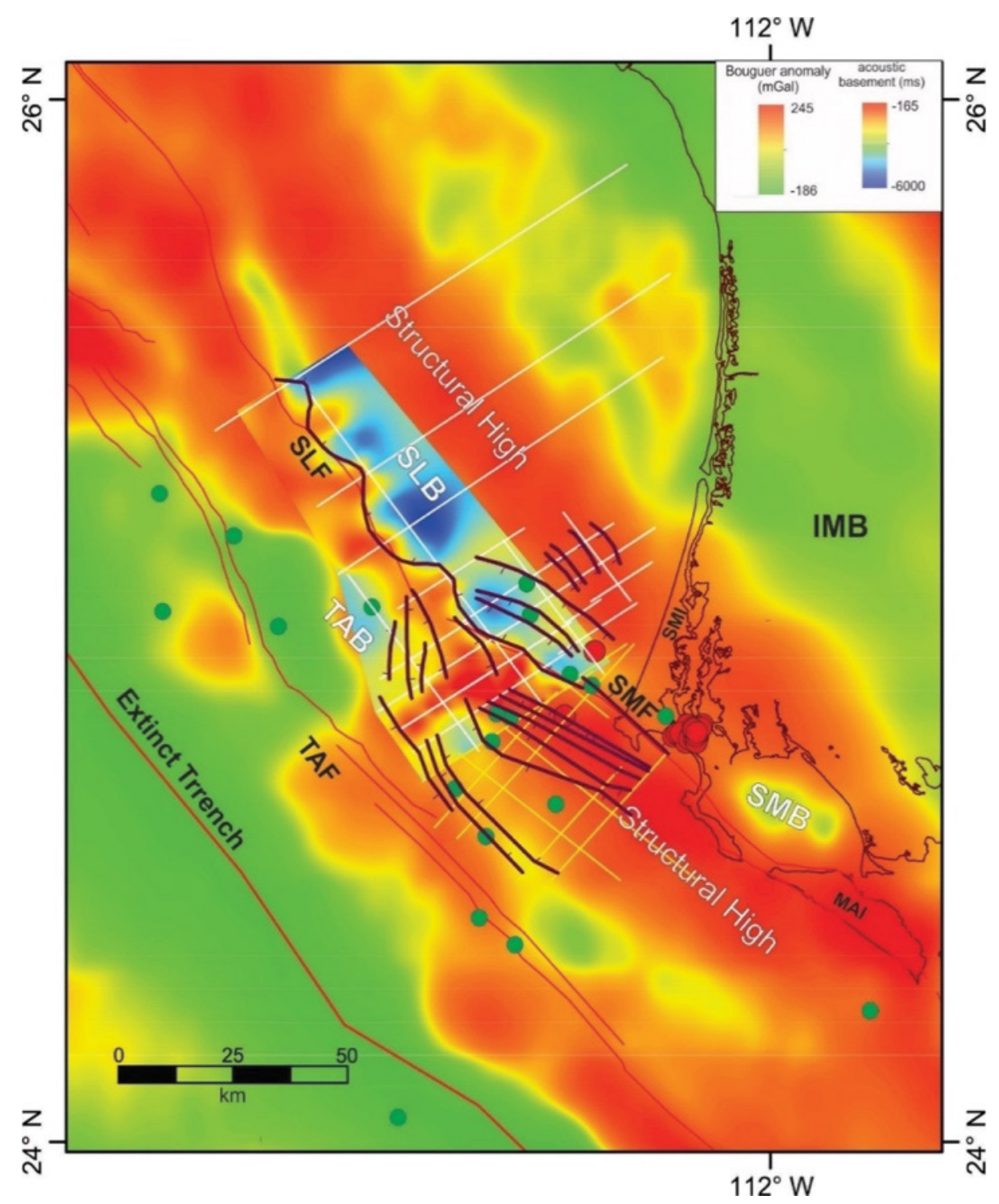

Figure 6: Interpretation of the faults and acoustic basement. The interpretation of faults in the region included the report by [10]. Included in the results are the trace of the San Lázaro and Sana Margarita Faults (SLF, SMF), obtained from seismic interpretation and the traces of these faults in previous work of [10], and information of [1] and [25]. Red and green circles are the seismicity reported by [19]). SMB: Santa Margarita Basin. The Bouguer anomaly include is from [18].

the oceanic and continental crust.

We interpreted eight stratigraphic packages of which three of them ( $A, B$ and $C$ ) correspond to those observed and reported previously, south of this work $[10,25]$ and the packages represent velocities (Figure 7). The sedimentary packages A, B, and $C$ are dominant throughout the region. The detected reflectors tend to be deeper from NE to SW on the Shelf, and at the same time their thicknesses are larger in the same direction, this was observed as the packages are wedged towards the coast. This fall causes the formation of deep basins, where new thinner packages that fill the depocenters begin to appear.
The construction of a three-dimensional geophysical model was possible by analyzing profiles forming a net, by interpolating the different seismic reflectors that functioned as sequence limits, considering the faults that control the shape of the structures (Figure 7). The isolation of the various stratigraphic units was done by joining the limits of the sequence and the properties obtained from the velocity by the semblance method, where the velocity of the units tends to increase with depth.

The Magdalena Shelf sector is controlled by two dominant trends corresponding to two fault systems in the NW-SE direction; Tosco-Abreojos and San Lázaro (Figure 8). It is inferred that these faults 


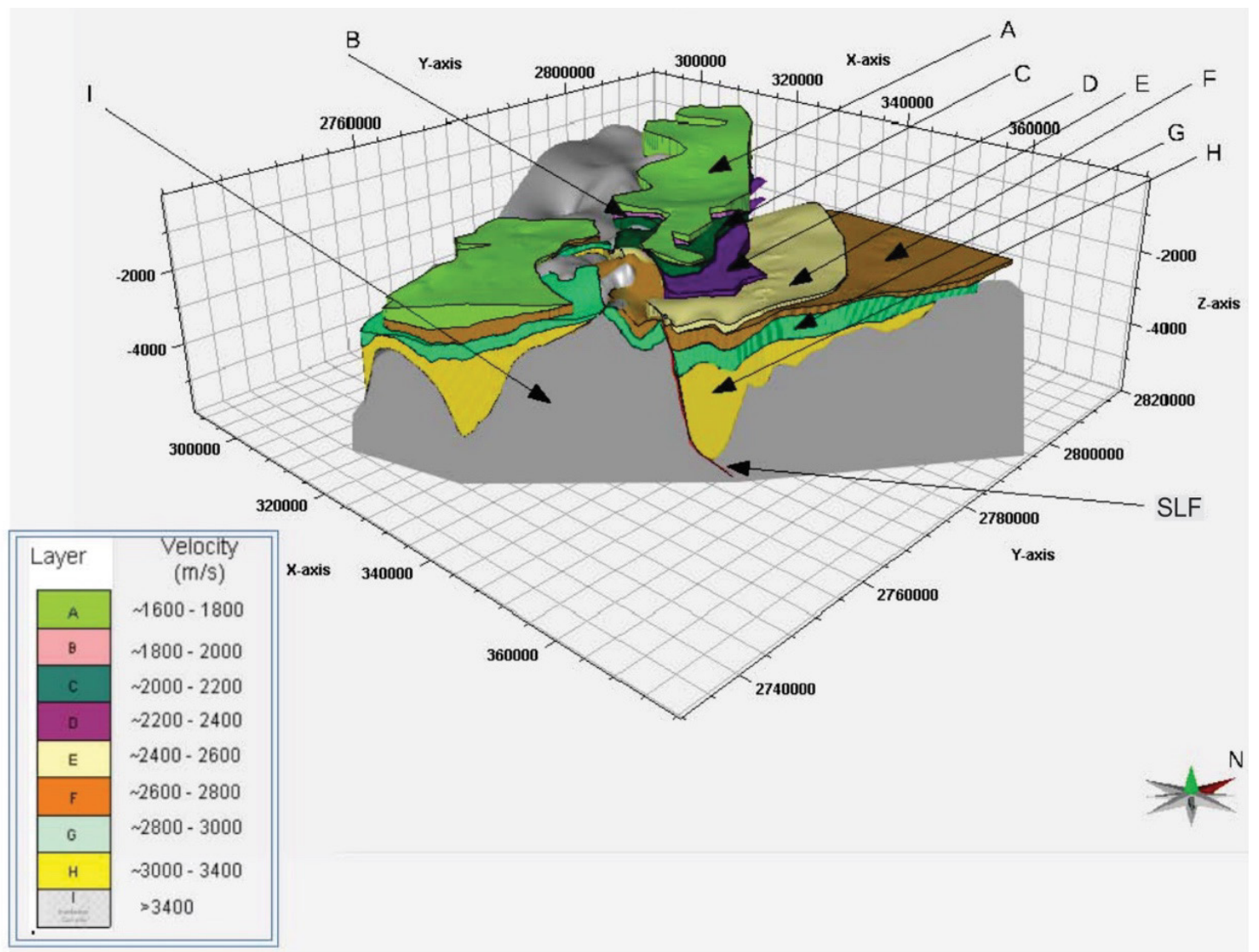

Figure 7: A three-dimensional stratigraphic model with the effect of display SE-NW. SLF: San Lazaro Fault.

displace the sediments and control the morphology of the basins. The Tosco-Abreojos fault is not present in the seismic profiles of this work, but it is observed in the geomorphology of the seabed, and it is the one that controls the basin of the same name. This fault is regional, while the San Lazaro fault is relayed with the Santa Margarita fault (Figure 8) and with a normal-type listric geometry submerged in the depression, San Lázaro. Therefore, the areas affected by these faults are associated with relatively deep asymmetric basins that contain divergent stratigraphic packages. Both basins are deeper towards the northwest. The main contribution of the sediment to the basins comes from the continental arc of Baja California, as suggested [26].

\section{Discussion}

When comparing the characterization of the San Lázaro fault based on studies of the seafloor morphology $[10,17]$, with the interpretation in the present work, it can be observed that the results are very similar, and the same happens with the faults reported by [19] in the seismic profiles south of the study area of this project. The presence of the fault is also confirmed by the complete Bouguer anomaly (Figure 8), with data obtained from [18].

It is considered that the San Lázaro fault is active according to seismological data reported from 1960 to the present, according to the National Center for Earthquake Information (NEIC) and work on microseismicity in the San Carlos region, B.C, [19]. The interpretation of the San Lazaro-Santa Margarita fault indicates that these structures are relays between them, taking into account also what was reported by [10], and including the characteristics of the complete Bouguer anomaly of the map constructed from the data of [18]. The Santa Margarita fault experiences a displacement from $E$ to $W$ to continue to the northwest with the relay of the San Lázaro fault. Regarding the acoustic basement, this is associated with the ophiolite subduction complex $[2,10,25]$. The correlation of this basement (high structural) with the complete anomaly map of Bouguer, is represented by high gravimetric values, which can be observed in all the seismic lines (Figure 8).

The alignments of the gravity anomalies suggest the continuation of the structural height to the 
A)

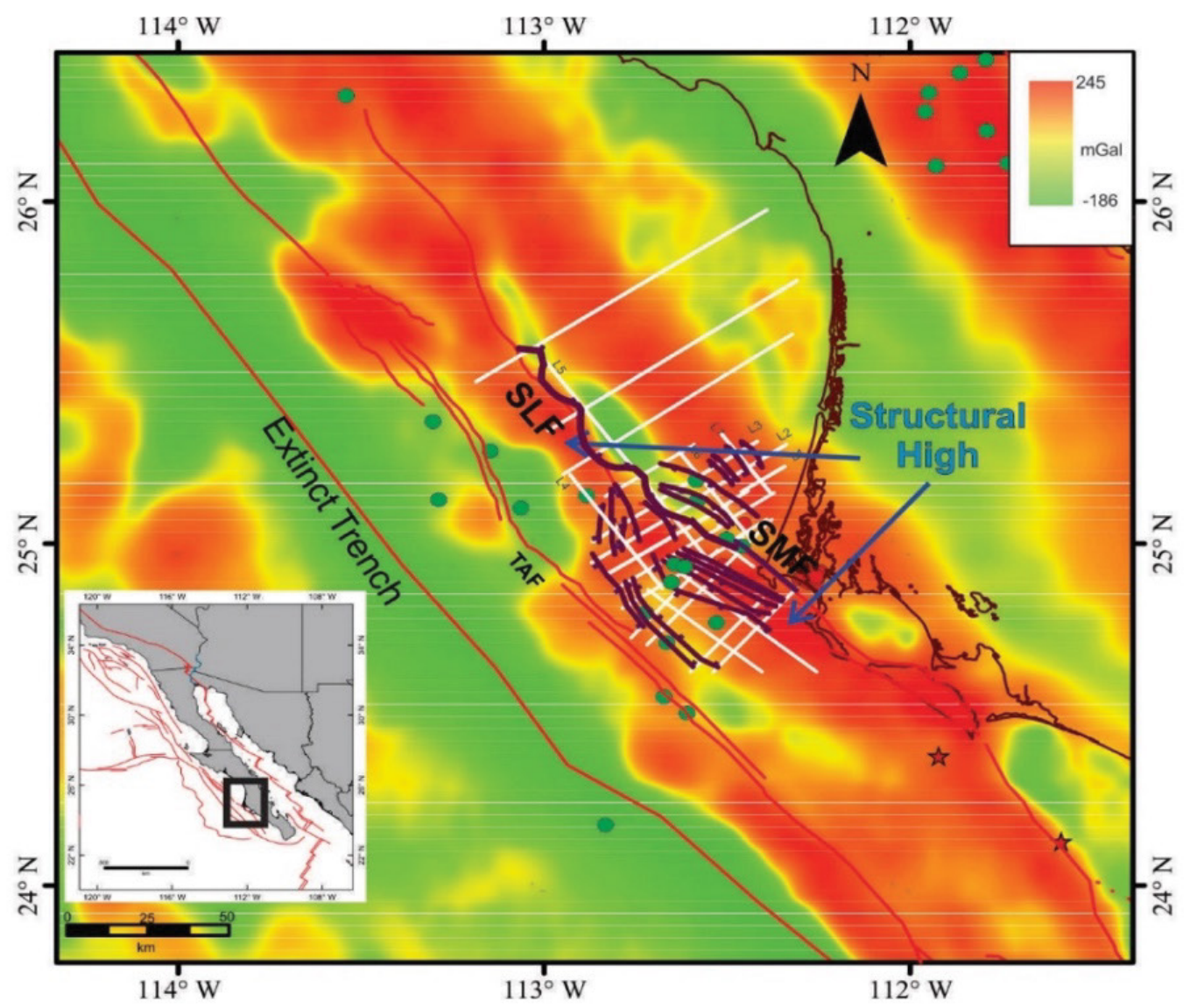

B)

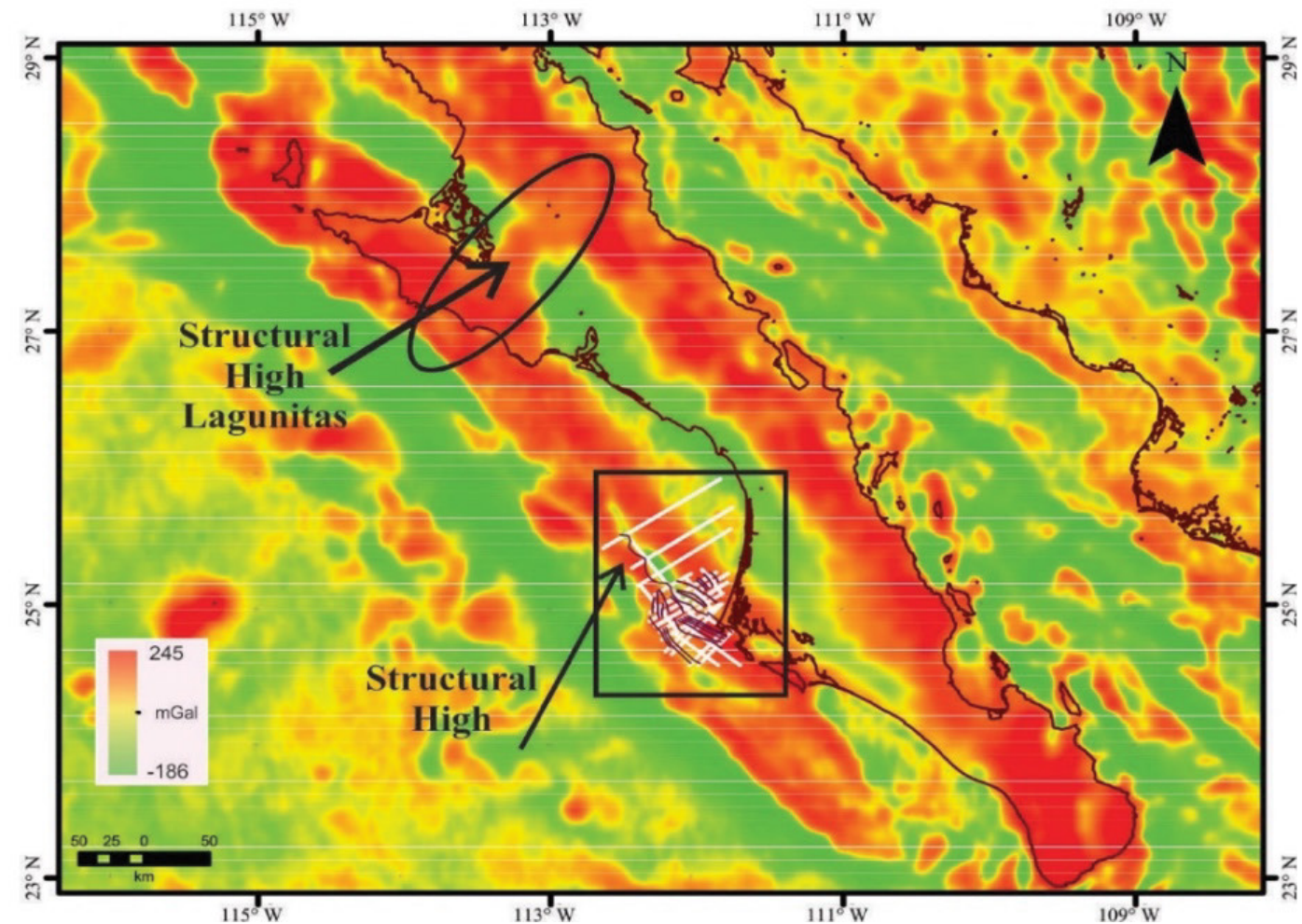

Figure 8: Structures obtained with seismic reflection data and Bouguer anomaly from [18]. The study area lies within the black box. A) SLF: San Lazaro Fault; SMF: Santa Margarita Fault; TAB: Tosco-Abreojos Fault and ophiolite high structural. Red and green circles are the seismicity reported by [19]. B) Bouguer anomaly map with the regional distribution of the structural high, as well as the height of Lagunitas structure described by $[24,27]$. 
northwest of the Magdalena Shelf and the Lagunitas (Figure 8), in the Vizcaíno region, BC, where a structural height known as Arco Lagunitas has been reported by [27]. These structures are associated with one since both bodies are constituted by ophiolite rock. The Arco Lagunitas is a transverse block oriented NE-SW and corresponds to rocks of the Jurassic-Cretaceous age [24], while the basement observed in a well in the central region of the Magdalena Shelf (north of the study area), associated with rocks belonging to the Triassic-Jurassic according to [24]. So, the Arco de Lagunitas is more recent than the structural high located on the Magdalena Shelf, even though both are formed by ophiolite rock. The basins were characterized by interpreted seismic horizons and the complete anomaly map of Bouguer (Figure 5) of [18]. The distribution and thickness of the basins become deeper to the northwest, estimating depths of up to $\sim 4$ $\mathrm{km}$ in the Tosco-Abreojos basin and up to $\sim 5.5 \mathrm{~km}$ in the San Lázaro basin. The sedimentary packages A, B and C (seismostratigraphic units) can be compared and associated with packages observed from the southeast by $[2,10]$, where $[2,10]$ suggest that they are units around $13-8 \mathrm{Ma}$ of age. The upper units identified are associated with the most recent ages of the Neogene.

Making a comparison of the Magdalena Shelf with the region of the island of Crete, where the forearc of the Hellenic subduction zone is located, in the transition area between the African and Eurasian plates [9]. In both cases, there are normal faults that typically consist of dip slides from 4 to 20 $\mathrm{km}$ long, in segments present locally in more complex fault zones. For both cases, the faults show clear evidence that they are active. Although these contractional structures can generate strong seismic events $(M \approx 7.5)$, these are not common and, therefore, provide a minor contribution to the evolution of these basins. A big difference in both basins is that in Crete, the seismic activity is stronger, both in a number of earthquakes and magnitude in comparison to what happens in Magdalena Shelf. The evolution in the main sedimentary sequences in both Crete and Magdalena, in contrast to most of the adjustments of the forearc basins in the Pacific and Indian Oceans, both regions are predominantly oblique. However, in the case of Crete, it is located in one of the most active seismic zones in Europe [9], while the historical seismicity in Magdalena does not show evidence of great historical seismic activity [10]

\section{Conclusions}

Research in the Pacific Ocean on the western margin of Baja California Sur has generated new knowledge about the structures that control the development of the Tosco-Abreojos and San Lázaro basins, and the processes that gave rise to the formation of the Magdalena Shelf. The conclusion of the evolution of the two semi-graben is that both are part of the process of complex subduction in the basin before arc, and these are controlled by two systems of major faults identified as; Tosco-Abreojos and Santa Margarita-San Lazaro, however, and minor extensional faults control part of the deformation of the depocenters of the basins.

The faults identified in the study area are of the normal type since the regional area originally had initially convergent and subsequently have divergent stress, as a consequence of the end of the subduction in the middle Miocene. Afterward, a new system of stress was initiated during the capture of the microplate of Baja California by the Pacific plate during the formation of the new oceanic continental crack of the Gulf of California. In both basins, there are eight sedimentary packages identified from the seismic reflectors. However, only three dominant units (large thickness), can be differentiated by presenting strong reflectors with high contrast between their amplitudes, which can be correlated with the seismostratigraphic units reported to the southeast by [2]. It is considered that the sedimentary packages are regional and extend towards the northwest and the southeast along the whole basin, however, the less dominant and less deep packages cover and fill the spaces generated.

The strike of the San Lazaro fault proposed at the beginning by $[10,17]$, based on the morphology of the ocean floor is confirmed by the interpretation of the seismic sections of this study, where the morphology of the fault is detailed. The San Lázaro fault is interpreted as an interruption of the continuity of the acoustic basement, in a vertical jump of $\sim 2 s$ (TWTT). It is considered a normal regional fault that marks the boundary of the San Lazaro basin in the west and it deduces that it extends $70 \mathrm{~km}$ northwest of the study area $-113^{\circ}$ of longitude and $26^{\circ}$ of latitude, according to the gravimetric data evidence [18]. This fault in its interpretation shows a more sinuous form than that reported by other authors $[17,25]$; however, as shown in the L-5 
profile (Figure 2), this structure (fault) is cut several times by the same seismic profile. Given that the San Lazaro fault cuts the seabed and the region presents seismic activity [19], this is active. The seismic-stratigraphic model proposed, with the results obtained here and collected, is a regional model because the processed lines are spaced from each other every $5 \mathrm{~km}$, and there are areas where there is no information, resulting in a low resolution.

\section{Author Contributions}

Mastache-Román, E.A processed the seismic reflection data, checked regional geology settings and did a new local geology interpretation results, this article is the results of the Master's Thesis. González-Escobar, M. led the research, checked the consistency of the processing flows of the seismic data and validated the new local geologic interpretation results, project administration.

\section{Acknowledgements}

This research was funded by a scholarship from CONACYT. The Landmark University Grant Program (2008-UGP-008005 to CICESE), OpendTect V5.0 provided licenses for the use of software and Google Earth Pro grant Educators. Discussions with Ramón Mendoza, M. Pacheco, and Clemente Gallardo are acknowledged. We thank Sergio Arregui for technical support.

\section{References}

1. Atwater T, Stock J (1998) Pacific-North America plate tectonics of the Neogene southwestern United States: An update. International Geology Review 40: 375-402.

2. Brothers $D$, Harding A, González Fernández A, Holbrook WS, Kent G, et al. (2012) Farallon slab detachment and deformation of the Magdalena Shelf, southern Baja California. Geophysical Research Letters 39.

3. Dixon T, Farina F, DeMets C, Suarez-Vidal F, Fletcher J, et al. (2000) New kinematic models for Pacific-North America motion from 3 ma to present, II: Evidence for a" Baja California shear zone. Geophys Res Lett 27: 3961-3964.

4. Michaud F, Sosson M, Royer JY, Chabert A, Bourgois J, et al. (2004) Motion partitioning between the pacific plate, Baja California and the North America plate: The Tosco Abreojos fault revisited. Geophysical Research Letters 31.

5. Plattner C, Malservisi R, Govers R (2009) On the plate boundary forces that drive and resist Baja California motion. Geology 37: 359-362.

6. Bohannon RG, Parsons T (1995) Tectonic implications of post-30 Ma Pacific and North American relative plate motions. GSA Bulletin 107: 937-959.

7. Tankard AJ (2002) Tectonic framework of basin evolution in Peru.

8. Dickinson W (1995) Forearc basins. In: Ingersoll y Busby, Tectonics of Sedimentary Basins. Blackwell Science, Berlin, 260.

9. Alves TM, Lykousis V, Sakellariou D, Alexandri $S$, Nomikou P (2007) Constraining the origin and evolution of confined turbidite systems: Southern Cretan margin, Eastern Mediterranean Sea (34 30-36 N). Geo-Marine Letters 27: 41.

10.González-Escobar M, Salazar-Cárdenas R, Munguía L, Martín A, Suárez-Vidal F (2016) Structural and seismic stratigraphic study in the center of the Magdalena shelf in the western margin of Baja California based on seismic reflection data. Geodynamics of the Latin American Pacific Margin 173: 3645-3661.

11.Paul J Umhoefer, Rebecca J Dorsey, Shawn Willsey, Larry Mayer, Paul Renne (2001) Stratigraphy and geochronology of the Comondú Group near Loreto, Baja California Sur, Mexico. Sediment Geol 144: 125147.

12. Miall AD (1990) Principles of sedimentary basin analysis. ( $\left.2^{\text {nd }} e d n\right)$, Springer-Verlag, New York, 633: 499.

13.Stock JM, Hodges KV (1989) Pre-pliocene extension around the Gulf of California and the transfer of Baja California to the Pacific Plate. Tectonics 8: 99-115.

14.Lonsdale $P$ (1991) Structural patterns of the pacific floor offshore of peninsular California. The gulf and peninsular province of the Californias 47: 87-125.

15. Kimbrough DL, Smith DP, Mahoney JB, Moore TE, Grove M, et al. (2001) Forearc-basin sedimentary response to rapid Late Cretaceous batholith emplacement in the Peninsular Ranges of southern and Baja California. Geology 29: 491-494.

16. Michaud F, Royer JY, Bourgois J, Dyment J, Calmus T, et al. (2006) Oceanic-ridge subduction vs. slab break off: Plate tectonic evolution along the Baja California Sur continental margin since $15 \mathrm{Ma}$. Geology 34: 1316.

17.Spencer JE, Normark WR (1979) Tosco-Abreojos fault zone: A Neogene transform plate boundary within the Pacific margin of southern Baja California, Mexico. Geology 7: 554-557.

18.Sandwell DT, Müller RD, Smith WHF, Garcia E, Fran- 
cis R (2014) New global marine gravity model from CryoSat- 2 and Jason-1 reveals buried tectonic structure. Science 346: 65-67.

19.Munguía L, González-Escobar M, Navarro M, Valdez T, Mayer S, et al. (2015) Active crustal deformation in the area of San Carlos, Baja California Sur, Mexico as shown by data of local earthquake sequences. Pure Appl Geophys 173: 3631-3644.

20.Yilmaz Ö (2001) Seismic data analysis. Tulsa, Ok: Society of Exploration Geophysicists.

21.Badley ME (1985) Practical seismic interpretation. International Human Resources Development Corporation, Boston, 257.

22.Landmark Software (2003) Landmark Graphics Corporation, 2001-2003.

23.Kimbrough DL, Moore TE (2003) Ophiolite and volcanic arc assemblages on the Vizcaino Peninsula and Cedros Island, Baja California Sur, Mexico: Mesozoic forearc lithosphere of the Cordilleran magmatic arc. Tectonic Evolution of Northwestern México and the Southwestern USA 374: 43.

24. Bailey EH, Blake MC Jr, Jones DL (2970) On land oceanic crust in California coast ranges. US Geol Survey, Prof. Paper, 2970, 700-c, 70-81.

25. Fletcher JM, Grove M, Kimbrough D, Lovera O, Gehrels GE (2007) Ridge-trench interactions and the Neogene tectonic evolution of the Magdalena shelf and southern Gulf of California: Insights from detrital zircon $\mathrm{U}-\mathrm{Pb}$ ages from the Magdalena fan and adjacent areas. Geological Society of America Bulletin 119: 1313-1336.

26. Ingersoll RV, Busby C (1995) Tectonics of sedimentary basins. Blackwell Science 35-46.

27. Lozano-Romen F (1975) Evaluación petrolífera de la península de Baja California, Mex. Boletín De La Asociación Mexicana De Geólogos Petroleros 27: 4-6. 